\title{
A Comparative Relationship Between Thyroid Gland And Body Weight: A Study in Foetuses of Different Ages
}

\author{
Dr. N. N. Srivastava ${ }^{1}$ Nand Kishor Gupta ${ }^{2}$, Dr Adil Asghar ${ }^{3}$, Dr Jayant Kumar \\ Verma $^{4}$, Dr Monika Srivastava ${ }^{2}$ \\ Professor $^{1}$, Lecturer $^{2}$, Assistant Professor ${ }^{3}$ Associate Professor ${ }^{4}$ \\ Department Of Anatomy, Up University Of Medical Sciences, Saifai, Etawah Up.
}

\begin{abstract}
Objective: To investigate the morphological structure and variation of thyroid gland in fetuses.

Formalin fixed 40 aborted fetuses from 16weeks -36 weeks of gestational age were dissected to study the morphology of fetal thyroid glands. Crown -Rump length, and weight of the fetus along with fetal thyroid morphological and morphometric parameters were recorded. We observed the broader right lobes, broader left lobes of the thyroid glands, pyramidal lobe, levator glandulae thyroidae and isthmus agenesis which may consider under multiple morphological anomalies of the thyroid gland. The morphological parameters of the both broader right and left lobes of the thyroid glands of the fetuses were recorded. This study highlights various developmental anomalies of the thyroid gland, thereby forming a corner stone to safe and effective surgery.
\end{abstract}

Keywords: Agenesis of isthmus, pyramidal lobe, variation lobes.

\section{Introduction}

It is a large ductless gland in the neck which secretes hormones regulating growth and development of body through the rate of metabolism. [1]

The thyroid has two lobes that lie on either side of trachea and is usually connected by a narrow strip of thyroid tissue called as isthmus. Some thyroid gland does not have an isthmus, and instead have two separate thyroid lobes. [2]

The thyroid gland is one of the larger endocrine glands, weighing 2-3 gm in neonates and $25 \mathrm{gm}$ in adults, and is increased in pregnancy. Each lobe is approximately $5 * 3 * 2 \mathrm{~cm}$ in length, width and thickness respectively. The gland itself is usually larger in women. The isthmus of the thyroid gland connects together the lower thirds of the right and left lobes of the thyroid gland. The isthmus measures about $1.25 * 1.25 \mathrm{~cm}$ in breadth and width and present in front of $2^{\text {nd }}$ and $3^{\text {rd }}$ ring of trachea. There may be variations in its size and situation. [3] An anastomosis of superior thyroid artery is present along the upper border and inferior thyroid veins along lower border. The thyroid gland is covered by a thin fibrous sheath, the capsule of the thyroid. The anterior layer is continuous with pretracheal fascia and postero-laterally continous with the carotid sheath. The gland is covered anteriorly with infrahyoid muscles and laterally with the sternocleidomastoid muscle. On the posterior side, the gland is fixed to cricoids and tracheal ring cartilages and cricopharyngeus muscle by a thickening of the fascia to form the posterior suspensory ligament of thyroid gland also known as ligament of berry. Two parathyroid glands usually lies on each side between the two layers of the capsule, at the back of thyroid lobes.[4] Over the next few weeks, it migrates to the base of the neck, passing in front of the hyoid bone. During migration, the thyroid remains connected to the tongue by a narrow canal, the thyroglossal duct. At the end of the fifth week the thyroglossal duct degenerates and the detached thyroid continues on to its final position over the following two week.

Persistence of pyramidal lobe, thyroglossal cysts, agenesis of the thyroid gland and aberrant thyroid are the major developmental anomalies of the thyroid gland [5]. Accessory nodules or ectopic thyroid tissue of the thyroid are usually found at the embryonic origin of thyroid gland, at the foramen caecum, or on the lingual duct and thyroglossal tract within the tongue. [2,7] anomalies of the development of the thyroid gland distort the morphology of the gland may cause clinical functional disorders and various thyroid illnesses [6].

\section{Material And Method}

40 fetuses were collected at different time interval from department of Gynecology and obstetrics department of Utter Pradesh university of medical science (formerly UP rural institute of medical science \& research) Saifai Etawah. The fetuses were kept in jar of appropriate size containing 5 liters of $10 \%$ formalin solution. The age of fetus was determined by case history of mother and correlated with the fetal parameter like 
crown rump length, head circumference and femur length. The weight was taken individually and each fetus was placed in separate formalin jar labeled with age of particular fetus.

\section{Dissection Of Thyroid Gland}

Each fetus was dissected to expose thyroid gland. After washing in running water to clear of formalin it was laid in supine position in the dissection tray. An incision was made from chin to sterna notch. Another incision from chin to either side below mandible and third incision parallel to clavicle. The skin flaps are reflected on either side. Sternohyoid sternothyroid and thyrohyoid muscles are cut and reflected. The pretracheal fascia is removed gently. The fat and fibrous tissue is also removed.

After dissection of thyroid gland, first it was searched for gross ectopic tissue, then thyro-thymic connection. The thyroid gland is visualized under following headings

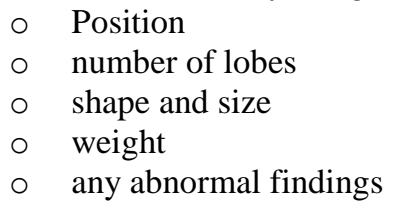

The main focus of study was the position of thyroid, Thyroid and body weight comparative study. The whole study was done after exposing thyroid lobes and separating from capsule and underlying trachea completely.

\section{Results}

This study included 40 fetuses of varying gestational age. The observations include the following steps.

1. All the fetuses were studied for any gross congenital anomaly.

2. Age of fetuses was determined individually.

3. The weight, fetal length and crown rump length were measured.

4. After exposing the thyroid gland, the gland is studied in terms of position, color and number of lobes, abnormal connection, isthmus, maximum length, width and maximum thickness and lastly weight of gland.

All fetuses were divided into four broad groups depending upon the gestational age i.e.

\section{5-15 Wks \\ 16-25 Wks \\ 26-35 Wks \\ 36-40 Wks}

Gross study of Thyroid gland : Position of thyroid was studied in the following criteria

1. Above the cricoid cartilage level

2. At the level of cricoid cartilage

3. Below the level of cricoid cartilage

Table 1 : Position Of Fetal Thyroid Gland

\begin{tabular}{|c|c|c|c|c|c|}
\hline S.N & Age Group (In & \multirow{2}{*}{ No Of Foetuses } & \multicolumn{3}{|c|}{ Position Of Thyroid At Neck } \\
\cline { 3 - 5 }$\cdot$ & Weeks) & & Above Cricoid & At Cricoid & Below Cricoid \\
\hline 1 & $5-15$ & 4 & 0 & 4 & 0 \\
\hline 2 & $16-25$ & 10 & 2 & 8 & 0 \\
\hline 3 & $26-35$ & 8 & 0 & 8 & 0 \\
\hline 4 & $36-40$ & 18 & 0 & 14 & 4 \\
\hline 5 & Total & 40 & 2 & 34 & 4 \\
\hline
\end{tabular}


Congenital Anomaly - regarding gross congenital anomaly, 6 fetuses are found to be anomalied. Out of these six, two is scoliosis and four are anencephalic.

Table 2 Congenital Anomaly

\begin{tabular}{|c|c|c|c|}
\hline S.No. & Age Groups (In Weeks) & No. Of Fetus Studied & Congenital Anomaly \\
\hline 1 & $5-15$ & 4 & 0 \\
\hline 2 & $16-25$ & 10 & 4 \\
\hline 3 & $26-35$ & 8 & 0 \\
\hline 4 & $36-40$ & 18 & 2 \\
\hline 5 & Total & 40 & 6 \\
\hline
\end{tabular}

Table 3: Sex Related Congenital Anomaly

\begin{tabular}{|c|c|c|}
\hline Sex & Fetal Studied & Congenital Anomaly \\
\hline Male & 14 & 0 \\
\hline Female & 26 & 6 \\
\hline Total & 40 & 6 \\
\hline
\end{tabular}

Thyroid And Body Weight Ratio - Observation in the subsequent table shows that individually the weights of fetus were in increasingly order except some fetuses. In the same way, the weights of thyroid gland were also in increasing order with increasing gestational age.

Table 4: Thyroid Gland Weight/ Body Weight Ratio

\begin{tabular}{|c|c|c|c|c|c|c|c|}
\hline S.No. & $\begin{array}{c}\text { Age } \\
\text { Groups } \\
\text { (Weeks) }\end{array}$ & $\begin{array}{c}\text { No.Of } \\
\text { Fetuses } \\
\text { Studied }\end{array}$ & $\begin{array}{c}\text { Age } \\
(\text { Weeks) }\end{array}$ & Sex & $\begin{array}{c}\text { Body } \\
\text { Weight } \\
(\text { Gm) }\end{array}$ & $\begin{array}{c}\text { Thyroid } \\
\text { Weight } \\
\text { (Gm) }\end{array}$ & $\begin{array}{c}\text { Rotio Of Thyroid } \\
\text { Weight/Body Weight }\end{array}$ \\
\hline \multirow[t]{4}{*}{1} & \multirow{4}{*}{ 5-15 } & \multirow[t]{4}{*}{4} & 8 & $\mathrm{M}$ & 100 & 0.04 & $1: 2500$ \\
\hline & & & 9 & $\mathrm{M}$ & 105 & 0.05 & $1: 2100$ \\
\hline & & & 12 & $\mathrm{M}$ & 120 & 0.18 & $1: 6666$ \\
\hline & & & 13 & $\mathrm{M}$ & 150 & 0.20 & $1: 750$ \\
\hline \multirow[t]{10}{*}{2} & \multirow[t]{10}{*}{$16-25$} & \multirow[t]{10}{*}{10} & 20 & $\mathrm{~F}$ & 250 & 0.28 & $1: 8928$ \\
\hline & & & 20 & $\mathrm{~F}$ & 290 & 0.28 & $1: 1035$ \\
\hline & & & 21 & $\mathrm{~F}$ & 340 & 0.29 & $1: 1172$ \\
\hline & & & 21 & $\mathrm{~F}$ & 375 & 0.28 & $1: 1339$ \\
\hline & & & 22 & $\mathrm{M}$ & 450 & 0.30 & $1: 1500$ \\
\hline & & & 23 & $\mathrm{M}$ & 490 & 0.30 & $1: 1633$ \\
\hline & & & 24 & $\mathrm{~F}$ & 750 & 0.30 & $1: 2500$ \\
\hline & & & 25 & $\mathrm{~F}$ & 800 & 0.28 & $1: 2857$ \\
\hline & & & 26 & $\mathrm{M}$ & 880 & 0.28 & $1: 3142$ \\
\hline & & & 26 & $\mathrm{M}$ & 950 & 0.29 & $1: 3276$ \\
\hline \multirow[t]{8}{*}{3} & \multirow[t]{8}{*}{$26-35$} & \multirow[t]{8}{*}{8} & 27 & $\mathrm{M}$ & 1400 & 0.30 & $1: 4666$ \\
\hline & & & 27 & $M$ & 1530 & 0.31 & $1: 4935$ \\
\hline & & & 29 & $\mathrm{~F}$ & 1600 & 0.32 & $1: 5000$ \\
\hline & & & 30 & $\mathrm{~F}$ & 1650 & 0.32 & $1: 5156$ \\
\hline & & & 31 & $\mathrm{~F}$ & 1250 & 0.33 & $1: 3788$ \\
\hline & & & 32 & $\mathrm{~F}$ & 1300 & 0.32 & $1: 4062$ \\
\hline & & & 34 & $\mathrm{~F}$ & 1500 & 0.40 & $1: 3750$ \\
\hline & & & 35 & $\mathrm{~F}$ & 1550 & 0.40 & $1: 3875$ \\
\hline \multirow[t]{18}{*}{4} & \multirow[t]{18}{*}{$36-40$} & \multirow[t]{18}{*}{18} & 36 & $\mathrm{~F}$ & 1800 & 0.41 & $1: 4390$ \\
\hline & & & 36 & $\mathrm{~F}$ & 1900 & 0.42 & $1: 4524$ \\
\hline & & & 36 & $\mathrm{M}$ & 2000 & 0.43 & $1: 4651$ \\
\hline & & & 37 & $\mathrm{M}$ & 2050 & 0.43 & $1: 4767$ \\
\hline & & & 37 & $\mathrm{~F}$ & 2100 & 0.44 & $1: 4772$ \\
\hline & & & 37 & $\mathrm{~F}$ & 2200 & 0.45 & $1: 4888$ \\
\hline & & & 38 & $\mathrm{~F}$ & 2300 & 0.46 & $1: 5000$ \\
\hline & & & 38 & $\mathrm{~F}$ & 2350 & 0.46 & $1: 5108$ \\
\hline & & & 39 & $\mathrm{~F}$ & 2400 & 0.45 & $1: 5333$ \\
\hline & & & 39 & $\mathrm{~F}$ & 2450 & 0.45 & $1: 5444$ \\
\hline & & & 39 & $\mathrm{~F}$ & 2500 & 0.46 & $1: 5435$ \\
\hline & & & 39 & $\mathrm{~F}$ & 2550 & 0.46 & $1: 5543$ \\
\hline & & & 39 & $\mathrm{~F}$ & 2600 & 0.44 & $1: 5909$ \\
\hline & & & 40 & $\mathrm{~F}$ & 2650 & 0.46 & $1: 5761$ \\
\hline & & & 40 & $\mathrm{M}$ & 2450 & 0.45 & $1: 5444$ \\
\hline & & & 40 & $\mathrm{M}$ & 2600 & 0.44 & $1: 5909$ \\
\hline & & & 40 & $\mathrm{~F}$ & 2500 & 0.45 & $1: 5555$ \\
\hline & & & 40 & $\mathrm{~F}$ & 2550 & 0.44 & $1: 5795$ \\
\hline
\end{tabular}


A Comparative Relationship Between Thyroid Gland And Body Weight: A Study in...

Table 5: Average Values Of Body Weight, Thyroid Weight And Ratio Between Them

\begin{tabular}{|c|c|c|c|c|}
\hline S.No. & $\begin{array}{l}\text { Age Group } \\
\text { (Weeks) }\end{array}$ & Body Weight $(\mathbf{G m})$ & $\begin{array}{l}\text { Thyroid Gland Weight } \\
(\mathbf{G m})\end{array}$ & $\begin{array}{l}\text { Thyroid Gland/Body } \\
\text { Weight Ratio }\end{array}$ \\
\hline 1 & $5-15$ & 118.75 & 0.1175 & $1: 1011$ \\
\hline 2 & $16-25$ & 557.5 & 0.342 & $1: 1630$ \\
\hline 3 & $26-35$ & 1472.5 & 0.335 & $1: 4395$ \\
\hline 4 & $36-40$ & 2330 & 0.4444 & $1: 5242$ \\
\hline 5 & Total (5-40) & 1494.5 & 0.35125 & $1: 4255$ \\
\hline
\end{tabular}

Thyroid Morphology - Thyroid gland morphology is studied on the following criteria.

1. Right and left lobe with CRL

2. Average of right and left lobe with thyroid weight

3. Presence of accessory lobe

4. Thickness of right and left lobe in respect to length

5. Thyro-thymic connection.

Table 6 Average Of Crl/Length Of Both Lobes

\begin{tabular}{|c|c|c|c|c|c|}
\hline S.No. & $\begin{array}{c}\text { Age Groups (In } \\
\text { Weeks) }\end{array}$ & Crl (Cm) & $\begin{array}{c}\text { Ratio Of } \\
\text { Crl/Rt Lobe }\end{array}$ & $\begin{array}{c}\text { Ration Of } \\
\text { Crl/Lt Lobe }\end{array}$ & $\begin{array}{c}\text { Combined Ratio } \\
\text { Of Rt+Lt Lobe }\end{array}$ \\
\hline 1 & $5-15$ & 11.125 & $19.9: 01$ & $17.6: 01$ & $18.8: 01$ \\
\hline 2 & $16-25$ & 17.65 & $17.7: 01$ & $14.5: 01$ & $16.1: 01$ \\
\hline 3 & $26-35$ & 24.1625 & $17.6: 01$ & $17.4: 01$ & $17.5: 01$ \\
\hline 4 & $36-40$ & 30.4056 & $15.1: 01$ & $15.3: 01$ & $15.2: 01$ \\
\hline 5 & Total (5-40) & 24.04 & $16.7: 01$ & $15.7: 01$ & $16.2: 01$ \\
\hline
\end{tabular}

Presence of Accessory lobe - The accessory lobe is the one which is present somewhere around either of right and left lobe of thyroid gland.

Table 7: Accessory Thyroid Lobes

\begin{tabular}{|c|c|c|c|}
\hline S.No. & Age Groups (In Weeks) & Foetus Studied & Accessory Lobes \\
\hline 1 & $5-15$ & 4 & 0 \\
\hline 2 & $16-25$ & 10 & 2 \\
\hline 3 & $26-35$ & 8 & 2 \\
\hline 4 & $36-40$ & 18 & 2 \\
\hline 5 & Total (5-40) & 40 & 6 \\
\hline
\end{tabular}

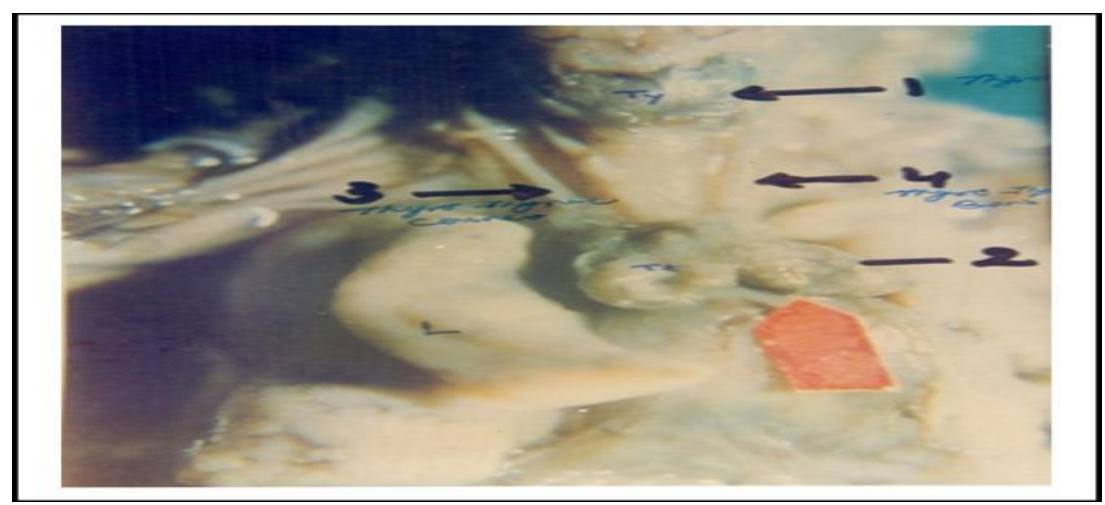

Figure-1 : Human foetal thyroid. (34 weeks) Showing thyro-thymic connection.

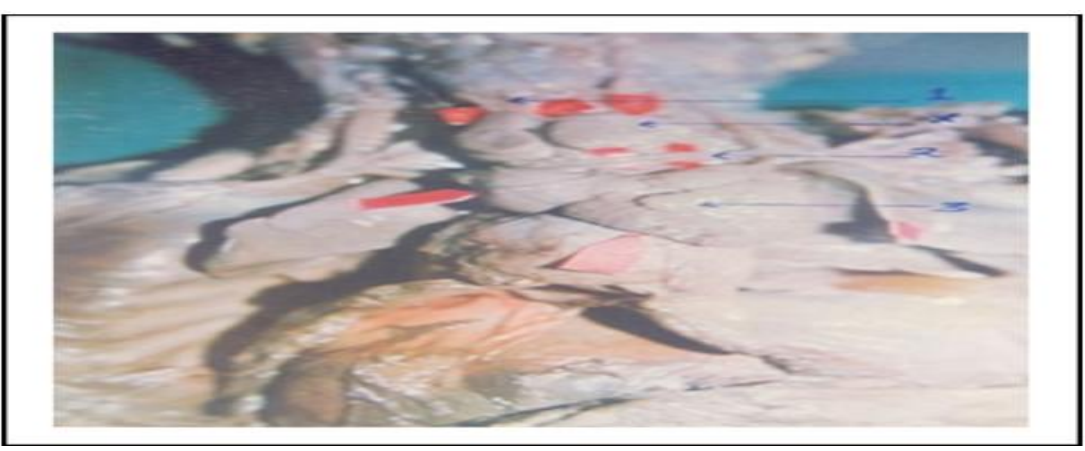

Figure-2: Human foetal thyroid. (29 weeks) 
1- Thyro-thymic connection.

2- Vascular bed between cervical \& thoracic part.

3- Thoracic part of thymus.

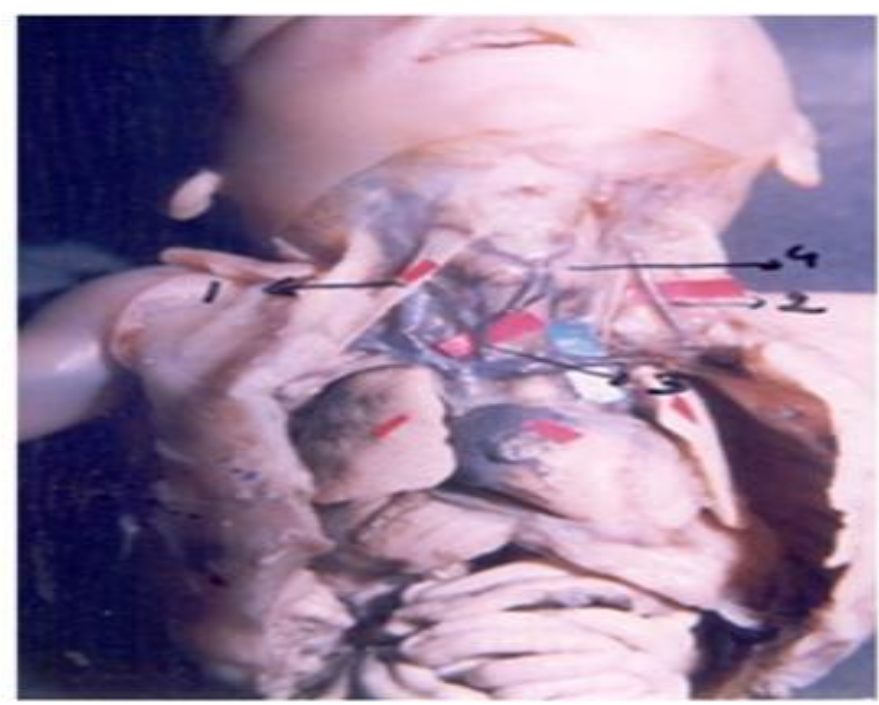

Figure-3: Human foetal thyroid. (26 weeks)

1- Sterno thyroid muscle.

2- Left juglar veing.

3- Inferior thyroid vein.

4- Thyroid lobe.

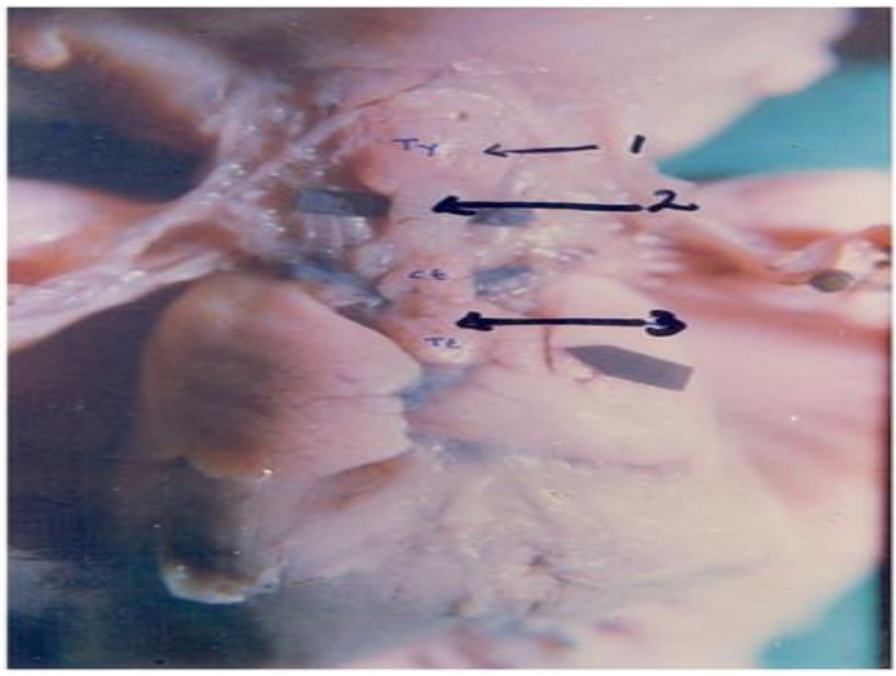

Figure-4: Human foetal thyroid. (38 weeks)

1- $\quad$ Thyroid Gland

2- Thyro-thymic connection

3- Thymus.

\section{Discussion}

Davis (1923) $1^{\text {st }}$ demonstrated that thyroid gland was $1^{\text {st }}$ identifiable in embryo of about 20 somite as a median thickening of endoderm in the floor of pharynx. Sagalitzer (1941) was explained that in normal development the thyroglossal duct is completely reabsorbed but it may persist in whole or in part. According to Langmans $`$ Medical embryology $6^{\text {th }}$ edition the thyroglossal duct later become solid and finally disappears.

According to Norris 1916, the tubular thyroglossal duct grows caudally and the tip bifurcate. Subsequently, the whole mass divides into series of double cellular plate, from which the isthmus and lateral tube of thyroid gland are developed. The primary thyroid follicle differentiated by reorganization and proliferation of cells of these plates. Secondary follicle subsequently arises by budding and sub division. 
According to Grey's, the fact that $4^{\text {th }}$ pharyngeal pouch contribution in development of thyroid gland may be disputed and perhaps seemed unlikely on the basis of comparative embryology.

The result of present study between thyroid gland weight and body weight confirms the earlier findings of JACKSON (1909) and SHEPARD et. al. (1964). The weight og gland is highly correlated with CRL of developing fetuses. Moreover, in accordance with earlier reports, no gender related differences in the weight of the gland were observed during the late fetal life.

The present study clearly reveals the continuous increase in the absolute volume of thyroid gland during second half of intra-uterine life. This growth is parallel to the increase in the weight and volume of the gland.

The present study also focus on the normal position of thyroid gland, after the descent of thyroglossal duct, their bifurcation and formation of lobed structure completed. In our study, in $85 \%$ of total fetuses studied, the position of thyroid gland is at the level of cricoid cartilage. However very little literature is available on this. In $15 \%$ of total fetuses studied (6 out of 40), the thyroid gland has accessory thyroid tissue (lobes).

In the present study we observed broader right lobes broader left lobes of the thyroid gland in 32 fetuses out of 40 gives the incidence of $80 \%$ of developmental nomalies along with the persistence of pyramidal lobe. he pyramidal lobe and the band develop from remnants $f$ the epithelium and connective tissue of the thyroglossal duct [1]. Most of the variations of the thyroid gland are due o a partial persistence of the median thyroglossal duct [4].We also observed a female fetus with agenesis of isthmus ith isolated lobes. Failure of the development of the ntire gland, or part of the gland, results in agenesis or emi agenesis, which may be unilateral or isthmic [6-14]Many workers claim that the absence of isthmus is uite rare in humans[7,8]. The frequency of the presence of pyramidal lobes could be a source of pitfalls in hyroidectomy during preoperative diagnosis on images [9].Braun et al. [9] reported a pyramidal lobe was found to be present in $55 \%$ of the cadavers and it was found more frequently in men than in omen. The frequency of the existence of the pyramidal lobe was $76.8 \%$ in a study performed to clarify the

\section{Conclusion}

The present study is performed in 40 fetuses of different gestational age. The aim of study was to localize the position of thyroid gland, its lobe, measurement and its relation with body weight. Also the position of Accessory thyroid tissue, if any and the possibility of any anomaly in development are taken into consideration. The results of study are as follows.

This study reveals that anatomical variations of the lobes and agenesis of the isthmus are considered as developmental anomalies, hereby forming a corner stone to safe and effective surgery. Knowledge of the thyroid anatomy and its associated anatomical variations is very much essential, so that these anomalies may not be overlooked in the differential diagnosis.

\section{References}

[1]. Hall, john (2011). Guyton and hall textbook of medical physiology (12 ${ }^{\text {th }}$ ed.).philadelphia, pa.:saunderselsevier.p 907.

[2]. Boron WF; Boulapep, EL.(2012).medical physiology ( $2^{\text {nd }}$ ed.). philadelphia:saunders.p.1052.

[3]. Longo, D; Fauci, A; Kasper, D; Hauser, S; jameson J; Loscalzo, J (2012). Harrison's principle of internal medicine (18 ${ }^{\text {th }}$ ed.).new York:Mc Graw-hill.pp.2913, 2918.

[4]. EDITOR-IN-CHIEF, Susan standring; section editors, Meil R Borley; et al. Grays anatomy:theanatomical basis of clinical practice (40 ${ }^{\text {th }}$ ed.). London:Churchill Livingstone. Pp. 462-464.

[5]. "Thyroid, parathyroid, adrenal, endocrine surgery, anatomy of the Thyroid Gland". www.endocrinesurgeon.co.uk.

[6]. Yalcin B.; Ozan H (February 2006). "detailed investigation of the relationship between the inferior laryngeal nerve including laryngeal branches and ligament of berry". Journal of the American College of Surgeons.202(2) :291-6.

[7]. Lemaire, David (2005-05-27). "emedicine-Thyroid Anatomy".

[8]. Kamath, M. Aroon "are the ligaments of berry the only reason why the thyroid moves up with deglutition?". Doctors Lounge Website.

[9]. Page,c; Cuvelier, P; Biet, A; Boute, P; M; Strunski, V (july 2009). 'thyroid tubercle of zuckerkandl: anatomical and surgical experience from 79 thyroidectomies.: the journal of laryngology and otology.123 (7): 768-71

[10]. Dorland's. illustrated medical dictionary. Elsevier Saunders.p.1072.

[11]. Cicekcibasi, AE; Salbacak, A; Seker, M; Ziylan, T; Buyukmumcu, M (april 2007). "development variations and clinical importance of the fetal thyroid. A morphometric study." Saudi medical journal.28(4):524-8.

[12]. Kim DW; Jung SL; Baek JH; et al. (jan 2013). "the prevalence and features of thyroid pyramidal lobe, accessory, and ectopic thyroid as assessed by CT:a multicenter study". Thyroid. 23 (1): 84-91

[13]. Fawcett, Don; jensh, Ronald (2002). Bloom and Fawcett's concise histology. New York Arnold publishers. pp. $257-258$.

[14]. Deakin, Barbora Young..et al. Wheater's functional histology : a text and colour atlas (5 ${ }^{\text {th }}$ ed.) Churchill livingstone/Elsevier. Pp. 333-335. 